\title{
Poverty and sustainable community development in Indonesia
}

\author{
A. Swaningrum ${ }^{1, *}$ \\ ${ }^{1}$ Leiden Ethnosystems and Development (LEAD) Programme, Leiden University \\ *Corresponding author: a.ayu.swaningrum@umail.leidenuniv.nl
}

\begin{abstract}
Global Poverty reduction has become an important issue nowadays, where according to United Nations; 36 Million people still live in extreme poverty. Poverty is acknowledged to be a major contributor to hunger and malnutrition, lack of health and education, increasing crime, diminishing socio-economic condition and a barrier for sustainable development. In line with the Post 2015 Development Agenda of the United Nations (2015) of Sustainable Development Goals (SDGs), the discussion of poverty has today become prominent especially in developing countries where a vast majority of world's poor people are living.
\end{abstract}

This paper reviews some of some articles which discuss poverty and sustainable development of developing countries. The main aim of this paper is to provide an overview of research which has explored poverty in the context of the effectiveness of the attempts to promote sustainable development in developing countries. In Indonesia, as one of many developing countries, the paper shows that the measurement of poverty in Indonesia has become important in order to not only to measure the actual level of poverty throughout the country annually in an objective way, but also to assess the cause of poverty itself. The related design of a realistic strategy of poverty reduction in Indonesia should be based on an integrative management approach which seeks to provide a combination of different services at the community level.

Keywords: Developing Countries, Poverty, Sustainable Community Development, Integrative Management Approach.

\section{INTRODUCTION}

This article reviews recent publications on poverty and sustainable development. It begins with an overview of poverty in developing countries, focusing on Indonesia in particular. Next to that it examines sustainable community development as a way of reducing poverty.

Many countries have a high GNP per capita, as a gauge of economic prosperity, but simultaneously suffer from high premature mortality, avoidable morbidities, high illiteracy rates, and high levels of unemployment among others, which indicate a low quality of life.

According to Sen (2003), the quality of life is related to the functioning and the capability to function of individual people. The evaluation of the quality of life cannot be limited to income. Poverty is regarded as a condition which has an adverse effect on the quality of life. Poverty has a correlation with well-being, and when poor people discuss well-being, they mention material, social, physical, psychological aspects, spiritual dimensions, self-esteem, as well as security, and the freedom of choice and action (Narayan, 2000; Maxwell, 1999). 
Poor people often have limited access to the financial system (Morduch, 2000) or health care, as shown by Peters et al (2008) who measured the geographical accessibility and availability of these services. We can regard poverty as a multidimensional condition which is not solely a result of financial status.

As indicated in the Multi-dimensional Poverty Index (Alkire et al, 2016) the condition of poor people can be assessed from personal consumption, access to education and health care, potable water and sanitation, housing, transport and communication. The MPI can be used as an analytical tool to identify the most vulnerable people, reveal which aspects they are deprived from, and show the interconnections between these deprivations. It would enable decision makers to allocate resources and design appropriate and effective policies.

\section{Poverty in Developing Countries}

Throughout the MDG period, poverty reduction was limited in developing countries, mainly income and access to safe water improved in more than half of all countries (Sumner \& Tiwari, 2011). From all developing countries, the percentage of participation in one of the following MDG categories shows: population earning less than $\$ 1 /$ day is $64 \%$, net enrolment ratio in primary education is $35 \%$, under 5 mortality rate (per 1000 live births) is $32 \%$, the use of improved sanitation facilities is $46 \%$ percent, use of safe drinking water is $76 \%$ (Fukuda-Parr \& Grenstein, 2010).

In Latin America, there was poverty reduction in the 1990's in Chile, Brazil, Uruguay, Costa Rica, Panama and the Dominican Republic, achieved through economic growth, creating higher employment and improved education and health conditions in the region. But after 2000 most of these success stories disappear, as in Panama, Brazil and Costa Rica (Morley, 2006).

According to the MPI research of Alkire \& Santos (2010), 57\% of the studied countries have over half of their population living in rural areas, including China and India. South Asia is home to approximately twice as many multidimensionally poor people as Africa. Living standard and education are the two indicators which contribute most to multidimensional poverty. In a regional comparison analysis, South Asia has the highest number of poor people (843, 8 million), followed by SubSaharan Africa (458 million), and East Asia \& the Pacific (255 million). In South Asia, 51\% of Pakistan's population is 'MPI' poor, 58\% in Bangladesh, 55\% in India, and 65\% in Nepal. In East Asia Pacific, Cambodia has 54\% of MPI poor, who on average are deprived in half of the (weighted) indicators. Indonesia is $21 \%$ MPI poor. Africa presents the highest MPI poverty rates. It ranges from 3\% in South Africa to 93\% in Niger, while the average percentage of deprivations varies between $44 \%$ in Swaziland to $69 \%$ in Niger.

\section{Poverty in Indonesia}

According to Human Development Report (2015), Indonesia ranks 110th with a value of 0.684 , with the Philippines ranking 116 with value 0.668 in the 'medium human development' category, low compared to the values of 0.726 for Thailand ranking 93, and 0.779 for Malaysia ranking 62nd both in the 'high human development' category in 2014.

The measurement of poverty in MPI is related to the Human Development Index (HDI) portray social and economic development. Indonesia is currently dealing with a complicated situation in its socio-economic development, despite the efforts of the government to improve the living conditions of the entire population. The majority 
of poor people in Indonesia live in rural areas, despite the rich and diverse national resources (Slikkerveer \& Ismawan, 2012; Bongartz 1989).

Regarding the Sustainable Development Goals targets 1.a and 1.b, all nations are expected to develop policies to fulfil the 2030 target of reducing poverty at least by half according to their national definitions. The economic development of Indonesia has led to a reduction of extreme poverty, but the income inequality and the number of children being left behind are also higher (Alisjahbana, 2016; UNICEF Annual Report, 2014).

Indonesia has the Nawa Cita and RPJMN (National Medium-Term Development Plan 2015-2019) programme which intersect with SDGs. In Indonesia, inequality has increased significantly from 0.31 (time at the decentralization was first introduced) to 0.41 (today), hampering development and also potentially threatening the stability of the country (UNDP, 2015). Indonesian statistics recorded that 20 percent of the richest people represent 48 percent of household's expenditure, while 40 percent of the poorest people represent 17 percent expenditure. Also, the three most spatial islands - Sumatra, Java and Bali - took 83 percent the regional GDP in 2014.

The RPJMN targets to reduce the Gini index to 0.36 at the end of 2019. The RPJMN also translates Nawa Cita into suburban development. Its purpose is to achieve decentralisation and balanced development, primarily in Eastern Indonesia, as well as poverty reduction. Poverty reduction policies alone may not be sufficient to reduce inequality significant enough to meet the Gini target in 2019. They should be combined with specific redistribution policies, covering fiscal and social protection. In addition to that they should include aspects of inequality that deal with access to health, education, and justice (UNDP, 2015).

The national framework is laid down in the National Medium Term Development Plan (RPJMN) 2015-2019 which focuses on poverty reduction by making the growth process to be more inclusive. Its target is narrowing the gap of consumption per capita between income groups and reducing poverty from 11,2 per cent in March 2014 to $6-8$ percent in 2019.

For the next five years, the government plans to reduce inequality and poverty through several means. The government will improve the investment climate for labour-intensive industries and small businesses to create more job opportunities. It will improve connectivity and accelerate the development of basic infrastructure to support economic activity and sustainable livelihood in rural and border areas. It will improve the delivery of basic social services such as education and health to the poor and vulnerable, as well as develop more comprehensive and specifically targeted social protection programs (Aji, 2015).

Slikkerveer (2008) states that there are basically two interrelated dimensions which depict the situation in Indonesia in its efforts to reach sustainable development: a) financial-economic dimension of the lack of an inclusive financial sector capable of reaching the rural poor and low-income groups. b) socio-educational dimension of impeded development of adequate education and training programmes in human resources to supply the development-oriented institutions and organisations with well-trained managers capable of extending an innovative system of integrated financial and social services to the poor. According to Slikkerveer \& Ismawan (2012), the two dimensions have come to the attention of the national government in its quest to find new ways to alleviate the poverty 
of the rural population within the context of development.

\section{Sustainable Community Development}

Sustainable community development is designed to improve the quality of life within communities with the characteristic to be environmentally sound, economically productive and socially just. To create full participation and a spirit of co-operation among the community members, so they can contribute to positive change in a sustainable society. This notion of sustainable community development has been successfully applied in real situation in Sarasota, a community in Florida, when it was facing urban growth, environmental degradation, traffic congestion, and also water scarcity in the mid1990's (Swisher \& Monaghan, 2003; Roseland, 2000).

As Stiglitz (2002) says, the process of participation should involve open dialogue and a broadly active civic engagement. All individuals should have a voice in the decisions which influence their life.

Sustainable development is an effort to mediate and find a balance between three areas of the development process: economy, community and ecology. Sustainable development is a challenging social process in which the objectives of society - social, economic and environmental need to be integrated (Brugmann, 1994; Bass, Dalal-Clayton \& Pretty, 1995). Another example is The Saemaul Undong Movement in Republic Of Korea, which improved both individual and community wellbeing [1] (ADB, 2012).

According to $\mathrm{Sr}$ (1996), community development is an acknowledgement of a community's social and economic condition which is utilised to overcome community problems, involving the government as well as
NGO's in the process. Hence, sustainable community development comprises behaviour which ascertains the meeting of the existing inhabitant's needs of a given community without harming the ability of future generations to meet their needs. Therefore sustainable community development can be considered as a form of development that avoids depletion, preserves the environment for future generations, and enhances the quality of life.

Sustainable community development should be carried out using a bottom-up approach which involves people's participation on territorial, ecological, cultural, social and economic factors through local empowerment (de Bekker \& Saefullah, 2012).

Sustainable development should assure that the poor have more options for their livelihood so that they will not exhaust resources, and develop the awareness that human beings need to work in harmony with their environment. (Bhushan, n.a). Examples of community development:

(i) Tourism development in Gili Trawangan, which altered the livelihood of local people from agriculture, fishing and herding small livestock, to become shopkeepers, restaurant's owners, souvenir sellers, boatmen, massage ladies, driving instructors and local tourist guides. The trading, hotel and restaurant sector have contributed $17 \%$ to GDP in NTB (Nusa Tenggara Barat) in 2012, and absorbed as much as $18 \%$ of total employment. This livelihood alteration makes local people's involvement in planning, decision-making and implementation prominent. It empowers local people to mobilise and manage their resources, become an active social actor, and control activities which will affect them (Kamsma \& Bras, 2000).

(ii) PNPM, national programme for urban and rural community empowerment (Voss, 2012) (Baker, 2013) [2], PNPM Mandiri is a community-driven development (CDD) which 
has been conducted in Indonesia since 1997. In the last few years, the government utilises the CDD approach regularly. It developed PNPM to a national level and integrated it as a main element of her reduction poverty strategy. With the signing of the Village Act (Act 6/2014 on the Village, the Village Law) at the beginning of 2014, the country adopted the principles of CDD and made it a policy. PNPM Mandiri procedures and processes will be used to implement the Village Law, in a transition period during the year 2015-2016. In early 2015, the central government transferred the grant funds to the district for further disbursement to 73,000 villages in 5,300 districts. (iii) Pemberdayaan Komunitas Adat Terpencil (Departemen Sosial RI, 2004). [3]

\section{The Integrative Management Approach for} Reduction Poverty

The three prominent keys of the integrative management approach are the utilisation of indigenous knowledge, promoting community participation, and integrating financial services with other services on community level.

These keys will increase gradual transformation of local institutions and organisations so that they could provide services like microfinance, health, education, communication and social support local people, especially the low-income and poor households. The utilisation of traditional institutions and organisations will allow local people to manage their resources in a sustainable way (Slikkerveer, Mustapha \& Saefullah, 2012), by using their indigenous knowledge. The importance of indigenous knowledge includes the following: (i) it encourages participatory decision-making and effective functioning of local organisations, (ii) it is a practical concept that can be used to facilitate communication among community members, (iii) it helps to assure that the end users of specific development projects, are involved in developing technology appropriate for their needs. (Phillips \& Titilola, 1995). The contribution of Indigenous knowledge as a locally managed, sustainable and cost-effective survival strategy should be promoted in the development process. It is social capital of the poor and a main asset to achieve control of their lives. (Gorjestani, 2000).

Community participation means empowerment of local people in development. There is an empirical study which shows that empowerment and participation is one of many critical factors to development (Khan, 2000; Elliot, 2006; Peters et.al., 2008). Empowerments constitutes a multidimensional and inter dependent social, political, economic and legal change process which enables poor and marginalised people to participate in shaping their futures (Eyben, Kabeer \& Cornwall, 2008).

As Alisjahbana (2016) says that successful SDG's implementation to reduce poverty does not merely depend on the central government's priority policies and programmes, but also on the active participation and collaboration of local administrations, the private sector, communities, non-governmental or academic organisations.

The people, who live, survive, and search for their livelihood are relying on assets like natural resources, social capital, financial capital and human resources. Education and health care should be accessible, supported by a physical infrastructure (Saragih, Lassa \& Ramli, 2007). It is important to integrate financial services with other human services on community level.

\section{METHOD}

This paper is an overview discussion in poverty and sustainable development area of interest from many types of writing such an annual reviews, scholarly journal articles, dissertations, and book. 


\section{DISCUSSION}

The Multidimensional Poverty Index is necessary for the measurement of absolute poverty, essentially because the index can be decomposed to identify which indicator / dimension should be prioritised. Measuring poverty in a specific location or a specific group is also essential since the awareness of their characteristics is important for the design of appropriate policies and programmes to reduce poverty. Poverty gauges become important in establishing the number of people who have been lifted above the poverty line. It is also used as an assessment of the extent to which a government is capable of alleviating poverty and meets its obligations to its citizen, as recorded in preamble UUD 1945, "Kemudian daripada itu untuk membentuk suatu pemerintah negara Indonesia yang melindungi segenap bangsa Indonesia dan seluruh tumpah darah Indonesia dan untuk memajukan kesejahteraan umum.....".

It is essential to understand the social and economic context, including institutions of the state, markets, communities, and households in studying poverty because there will be differences among groups, e.g. gender, where usually women suffer more than men; ethnicity; age, where often children suffer more than adults; or geographical location, e.g. rural poor people may be more deprived than urban.

\section{CONCLUDING REMARK}

As poverty is regarded as a process with many dimensions (economic and non-economic) and complexities, it also creates limitations to choices, interaction with employers, markets, the state, or even non-governmental organisations (Khan, 2000; Narayan, 2000). It could be overcome using an integrative management approach, integrating indigenous knowledge into ecological, economic and social dimensions.

Notes:

[1] Poverty reduction has impact on increasing household income; access to modern infrastructure and services brought about through mechanised farming, electrification, and improvement in the quality of housing, health services; empowerment of local communities and building social capital; revitalisation of community leadership; and acceptance of modern roles for woman in terms of overall social participation

[2] Pembangunan Nasional Pemberdayaan Masyarakat (PNPM), a government programme which is a key part in its poverty reduction strategy by delegating a portion of its portfolio to community-based programmes.

[3] This programme has been conducted in 12 provinces. The vision of Pemberdayaan Komunitas Adat Terpencil (Empowerment of remote indigenous communities) is attaining social welfare in remote indigenous communities which are independent in many aspects of life and livelihood. Its mission is (i) improve the fulfilment of basic human needs, (ii) equalise the basic social services, (iii) increase the social interaction with the advanced part of society, (iv) develop a system of social institutions in remote communities to support social resilience, and (v) increase an active role and social responsibility in development

\section{ACKNOWLEDGEMENT}

I would like to express my appreciation to Prof. Dr. Dr. (h.c). L. J. Slikkerveer for his guidance, encouragement and advice. My gratitude goes to the LEAD Programme for funding the publication of this paper and for supplying 
various important studies, which have been carried out in subfields of Ethnoscience.

Author is an awardee of LPDP scholarships. I thank to LPDP for funding the study at Leiden University.

\section{REFERENCE}

Agung, A.A.G. Bali Endangered Paradise? Tri Hita Karana and the Conservation of the Island's Biocultural Diversity. [Dissertation] The Netherlands: Leiden University; 2005

Alisjahbana, A. Focusing on Indonesia's SDGs Priorities [Internet]. Indonesia: the Jakarta Post; September 13, 2016. Available from http://www.thejakartapost.com/news/2016/0

9/13/focusing-indonesia-s-sdgpriorities.html

Ambaretnani, P. Paraji and Bidan in Rancaekek: Integrated Medicine for Advanced Partnerships among Traditional Birth Attendants and Community Midwives in the Sunda Area of West Java, Indonesia [Dissertation]. The Netherlands: Leiden University; 2012

ADB. The Saemaul Undong Movement in the Republic of Korea: Sharing Knowledge on Community-Driven Development. 2012. ISBN 978-92-9092-702-0 (Print), 978-929092-703-7 (PDF)

Aji, P. Summary of Indonesia's Poverty Analysis. 2015; ADB Papers on Indonesia No. 04.

Alkire, S. \& Jindra, C. \& Robles, G. \& Vaz, A. Multidimensional Poverty Index - Summer 2016. 2016; 4. OPHI Briefing 42

Alkire, S. \& Santos, M. E. Acute Multidimensional Poverty: A New Index for Developing Countries. 2010; No. 38. OPHI Working Paper
Baker, J., L. Indonesia; Evaluation of Community Driven Development Program. 2013. Kementerian Koordinator Bidang Kesejahteraan Rakyat \& PNPM Mandiri \& Kementerian Pekerjaan Umum dan Perumahan Rakyat.

Bongartz, H. Self-Help Organizations in Rural Java: A Case Study on Usaha Bersama Groups in Indonesia. Saarbrucken, Germany: Verlag Breitenbach Publishers; 1989

Brugmann, J. Enabling Sustainable Community Development. 1994; Environmentally Sustainable Development Proceedings Series No. 8. Opening Address

Bhushan, T. Poverty Alleviation and Sustainable Development-The Case for India. available from: http://ssrn.com/abstract=2044417

De Bekker, H. C. M. \& Saefullah, K. Governance, Policies, Rules and Regulations. In: Slikkerveer, L. J. Integrated Microfinance Management for Poverty Reduction and Sustainable Development in Indonesia. Bandung: LEAD-UL / UNPAD / MAICH / GEMA PKM; 2012. 128

Departemen Sosial RI. Profil Keberhasilan Pemberdayaan Komunitas Adat Terpencil pada 12 Provinsi. Jakarta: Direktorat Jenderal Pemberdayaan Sosial \& Direktorat Pemberdayaan Komunitas Adat Terpencil. Departemen Sosial RI; 2014

Djen Amar, S.C. Gunem Catur in the Sunda Region: Indigenous Communication on the Mac Plant Knowledge System within the Arisan in Lembang, West Java, Indonesia [Dissertation]. The Netherlands: Leiden University; 2010

Eyben, R., Kabeer, N., \& Cornwall, A. Conceptualising empowerment and the implications for pro poor growth. 2008. Report to DAC POVNET on empowerment.

Elliot, J. A. An Introduction to Sustainable Development. 2006; $3^{\text {rd }}$ ed. Routledge. Taylor \& Francis Group. 
Fukuda-Parr, S. \& Greenstein, J. How Should MDG Implementation Be Measured: Faster Progress or Meeting Targets. 2010; International Policy Centre Working Paper Number 63.

Global Monitoring Report 2014/2015. Ending Poverty and Sharing Prosperity. 2015; A Joint Publication of The World Bank and The International Monetary Fund.

Gorjestani, N. Indigenous Knowledge for Development. 2000. UNCTAD Conference on Traditional Knowledge in Geneva

Khan, M. H. Rural Poverty in Developing Countries: Issues and Policies. 2000; IMF Working Papers WP/00/78.

Kamsma, T. \& Bras, K. Gili Trawangan-from desert island to 'marginal' paradise: local participation, small-scale entrepreneurs and outside investors in an Indonesian tourist destination. In: Richards, G. \& Hall, D. Tourism and Sustainable Community Development. 2000. Routledge: Taylor \& Francis Group

Makasi, A. \& Govender, K. Globalization and Sustainable Development: A Conceptual Model. 2015; Mediterranian Journal of Social Science Vol. 6 No. 4 S3, August 2015. MCSER Publishing. Rome, Italia

Maxwell, S. The Meaning and Measurement of Poverty. ODI Poverty Briefing, 3 February 1999

Morduch, J. The Microfinance Schism. 2000; 28, No. 4, pp. 617 $\pm 629,2000$. Elsevier Science Ltd. Great Britain

Morley, S. A. Reducing Poverty in Developing Countries: Some Lessons from Latin America. 2006; Paper presented at the Vanderbilt 50th Anniversary Conference of the Vanderbilt Graduate Program for Economic Development. November 2006

Narayan, D. Poverty is Powerlessness and Voicelessness. 2000; Finance and Development: A Quarterly Magazine of IMF, December 2000, Volume 37, Number. 4
Peter, D. H. \& Garg, A. \& Bloom, G. \& Walker, D. G. \& Brieger, W. R. \& Rahman, M. H. (2008). Poverty and Access to Health Care in Developing Countries. 2008; Ann. N. Y. Acad. Sci. 1136: 161-171. Doi: 10.1196/annals. 1425.011

Phillips, A. O. \& Titilola, S. O. Sustainable Development and Indigenous Knowledge Systems in Nigeria : The Role of The Nigerian Institute of Social and economic Research (NISER). In: The Cultural Dimension of Development: Indigenous Knowledge Systems. Intermediate Technology Publications. 1995

Roseland, M. Sustainable Community Development: Integrating Environmental, Economic, And Social Objectives. 2000; Progress in Planning 54 (2000) 73-132. Pergamon

Saragih, S., Lassa, J., \& Ramli, A. Kerangka

Penghidupan Berkelanjutan. 2007; Buku Modul

Sen A. Development as Capability Expansion. In: Fukuda-Parr S, et al Readings in Human Development. 2003. New Delhi and New York: Oxford University Press.

Stiglitz, J. E. Participation and Development: Perspectives from the Comprehensive Development Paradigm. 2002; Review of Development Economics, 6(2): 163-182

Swisher, M. E. \& Monaghan, K. N. Sustainable Community Development. 2003. Available from http://edis.ifas.ufl.edu

Slikkerveer, L. J. \& Ismawan, B. Introduction to Integrated Finance Management in Indonesia. In: Slikkerveer, L. J. Integrated Microfinance Management for Poverty Reduction and Sustainable Development in Indonesia. Bandung: LEAD-UL / UNPAD / MAICH / GEMA PKM. 2012

Slikkerveer, L. J. \& Mustapha, H. K. \& Saefullah, K. Integrated Microfinance Management for Sustained Poverty Reduction. In: Slikkerveer, L. J. Integrated 
Microfinance Management for Poverty Reduction and Sustainable Development in Indonesia. Bandung: LEAD-UL / UNPAD / MAICH / GEMA PKM. 2012

Slikkerveer, L. J. (2008). Integrated Microfinance Management and Development in Indonesia, Project Proposal EVD/INDFD, LEAD, Leiden University.

Sr, K. R. H. Promoting Sustainable Community Development In Developing Countries: The Role Of Technology Transfer. 1996; Community Development Journal VOL 31 No. 3: Pp. 193-200

Sumner, A. \& Tiwari, M. Global Poverty Reduction to 2015 and Beyond. 2011; Global Policy Volume 2. Issue 2.

UNDP. Konvergensi Agenda Pembangunan: NawaCita, RPJMN dan SDGs. 2015; UNDP Indonesia Country Office.

Voss, J. PNPM Rural Impact Evaluation. 2012. Kementerian Koordinator Bidang Kesejahteraan Rakyat \& Bappenas \& PNPM 